Studia Anglica Posnaniensia 50/4, 2015

doi: 10.1515/stap-2015-0018

\title{
LINGUISTICS
}

\section{ANGLO-SCANDINAVIAN CODE-MIXING IN ENGLISH PLACE-NAMES}

\author{
TAMÁS FEKETE*
}

University of Pécs

\begin{abstract}
With this paper I wish to investigate the nature of code-mixing found in English place names chiefly, though not exclusively, from the Danelaw area. The paper analyses this code-mixing in the framework of contact linguistics in the light of the contact situation between Old English and Old Norse, as described by Townend (2002) and Lutz (2013), that existed from the $8^{\text {th }}$ century onwards, bearing in mind, however, that the Scandinavian place names may not necessarily be direct indicators of the nature and extent of the Scandinavian settlement itself. Historical code-switching usually and generally focuses on describing intersentential and intrasentential code-switching, and this paper aims at broadening the overall scope of the investigation through the inclusion of onomastics.

The analysis will be chiefly based on a corpus of 1,915 relevant place-names, with the data drawn from the Oxford Dictionary of English Place-Names (Mills 1998), and Fellows-Jensen's regional studies on Scandinavian place-names in England (Fellows-Jensen 1972, 1978, 1985). The primary focus of the investigation will be those place names which

(i) contain both Scandinavian and English elements,

(ii) used to contain at least one Scandinavian or English element which was replaced by an element from the other language,

(iii) contain at least one element which underwent a transformation to accommodate to the phonological system of the other language and

(iv) contain elements which could belong to either of the languages but cannot be decided with absolute certainty.
\end{abstract}

In this paper I also argue that names (specifically the above mentioned place-names) can conform to Muysken's (2000) category of congruent lexicalization and that word-internal code-switching, and CS in general, is in fact a phenomenon that can occur in the case of hybrid place-names.

Keywords: toponymy, code-switching, congruent lexicalization, Danelaw, language contact

* Corresponding author: Tamás Fekete (fekete.tamas@pte.hu), Institute of English Studies, University of Pécs, 7624 Pécs, Ifjúság útja 6, Hungary. 


\section{Introduction}

The phenomena of code-switching (CS) and code-mixing (CM) have received a considerable amount of scholarly attention, with a pronounced focus on syntax, especially on two major syntactic types: intrasentential and intersentential switching, analysed from a chiefly synchronic perspective (Muysken 2000, 2011, Bullock \& Toribio 2009), while historical aspects of CS have been somewhat backgrounded (Schendl \& Wright 2011). In contrast with this, the present paper is concerned with diachronic code-mixing on a lexical level, as it is observable and contained within the boundaries of compound words that function as appellatival place-names. The aim is to investigate the nature of $\mathrm{CM}$ found in Scandinavian-influenced and Anglo-Scandinavian hybrid place-name formations in England. It is argued that these hybrid names and the various manifestations of cognate substitution found in Scandinavianized settlement names are in fact instances of code-mixing consistent with Muysken's category of congruent lexicalization (Muysken 2000: 122-153).

\section{Place-names and the Scandinavian settlement in the British Isles}

The two major types of toponyms of Scandinavian origin which occur in the Danelaw area and the North West are purely Scandinavian names, containing only Old Norse elements (either from the Eastern or Western variety) and hybrid names, which are created by cognate substitution, Scandinavianized through phoneme substitution or created as an originally hybrid name. However, this last option can be subject to debate, because of the scarcity of written evidence available about the formation of these names and forms of toponyms that antedate the forms recorded in the Domesday Book, completed in 1086. This section surveys the possible origins of the English-Scandinavian hybrid toponyms in their historical context and also provides an overview of the possible linguistic relationship of the two affected languages.

2.1. Place-names, their meaning and the nature and extent of the Scandinavian settlement

It is a generally accepted fact that extensive Scandinavian contact with the English began in $793^{1}$, when raiding Vikings sacked the monastery in Lindisfarne, which was seventy years later followed by two distinct waves of raids, some 150 years apart, starting with the campaigns of the micel here, the great army of

1 Norwegian Vikings made very brief contact with the English before this in 787 when three of their boats arrived in Dorset (Loyn 1994: 38-39, Moskowich 2012: 21-23). 
the Danes in the autumn of 865 . This raid, unlike the earlier sacking of the monastery, was accompanied by settlement, especially after the battle of Edington, when Alfred, king of Wessex made peace with the Danes in 878. After the Treaty of Wedmore between Alfred and Guthrum, the Danes settled in the Danelaw area and then gradually assimilated into English society and began using the English language. The exact nature of the settlement can be subject to debate, as to whether a massive, coordinated migration took place with a wave of peasant migration following the settlement of the warriors of the great army (Fellows-Jensen 1968: xxii-xxiii, Cameron 1996: 75, Hadley 2000: 19-20), or whether only a relatively small group of high-ranking Viking soldiers settled, taking control of the north-eastern part of the England and then subsequently assimilating into the native population (Sawyer 1962) ${ }^{2}$. The place-name materi$\mathrm{al}^{3}$ seems to support the former setup, and the idea of a significant Norse presence in England, especially the fact that the most frequently occurring type of Scandinavian place-name is a habitative name ${ }^{4}$, which combines a Norse personal name and a Norse generic (547 instances, or 51.8\% out of 1,056 placenames with personal name specifics), leads one to believe that a rather large number of settlers migrated to this area and established their settlements on hitherto uninhabited pieces of land. On the other hand, those hybrid placenames (the so-called Grimston-hybrids) which contain a Scandinavian personal name and an English generic could suggest the presence of a Scandinavian overlord or owner of an otherwise English settlement. Based on this assumption it would seem likely that the Grimston-hybrids came about when Scandinavian invaders took over English settlements and the English generic was kept, but the specific was substituted with the name of the new owner (Fellows-Jensen 1985: 180, Reaney 1987: 170-171, Cameron 1996: 75). While this could definitely be true for the early stages of English-Norse contact and Scandinavian settlement, however another scenario also seems possible, which would presuppose the existence of a more advanced stage of population mixing between the English and the Scandinavians, namely that some hybrid names of this sort were created by English people who bore a Scandinavian personal name. Therefore without having knowledge about the exact date these names were formed, it is difficult to sort them into either of these two categories. Those place-names, however, which are made up of an English personal name and a Scandinavian generic

For a recent synthesizing discussion of the issue see Moskowich (2012: 32-36).

In a corpus of 1915 Scandinavian place-names, collected from SSNY, SSNEM, SSNNW, and Mills (1998). For a detailed discussion of the onomastic material see Sections 4 and 5 below.

$4 \quad$ Habitative names are defined here as names "which originally denoted some structure or structures used for habitation, shelter or other purposes by man or animal" (Fellows-Jensen 1978: 136). 
could reflect the exact opposite of this configuration, namely English dominance over a Scandinavian settlement, or that their owner was a Norseman bearing an English name, or, as will be shown later, that English speakers coined these names using a Scandinavian generic.

Furthermore, appellative hybrids (or Carlton-hybrids), which are made up of common nouns are also quite frequent (265, or $30.85 \%$ out of 859 appellatival place-names), but not nearly as much as pure Scandinavian formations (419, or $48.78 \%$ out of $859^{5}$ ). If the pieces of evidence which place-names can provide are taken together, then it may be assumed that:

(i) it is unlikely that only soldiers of the micel here settled in the area of the Danelaw,

(ii) the number and types of Norse place-names point to extensive and significant settlement by the Scandinavians, which is reflected by the dominance of habitative names, especially those in $b y^{66}$ village' and $p o r p^{7}$ 'secondary settlement, outlying farmstead',

(iii) Grimston-hybrids (or personal name hybrids) can indicate settlements with a mixed population, or that a village has probably undergone a change of ownership or the very least that a settlement has an overlord who bears a personal name of Scandinavian origin,

(iv) hybrid appellatival place-name formations and Scandinavianized names created via the substitution of cognate words reveal a degree of mutual intelligibility and mixing between the two languages, especially in those cases where the various attested forms show hesitation and the interchangeable use of English and Scandinavian elements (cf. FellowsJensen 1972: 112, 137, Townend 2002: $60^{8}$ ).

These place-names, however, should be handled with care, as Hadley (2000: 332-333) also calls attention to the fact that "it is not appropriate to make a simple connection between Scandinavian place-names and places of Scandinavian settlement". Indeed, due to the prevalence and outstanding frequency of place-names in $b y$ and borp, these generics could have easily found their way into English(cf. Janzén 1972: 8) and have become productive in the language,

See Table 1 below for further figures.

$585(48.79 \%)$ occurrences out of 1,199 tokens of Scandinavian generics in SSNY, SSNEM, SSNNW, and Mills (1998), see Table 2 below for further figures.

$7273(22.77 \%)$ occurrences out of 1,199 tokens (ibid.), see Table 2 below for further figures.

8 Townend (2002: 57-59) describes 192 instances of clear cognate substitution in Scandinavianized appellatival place-names, which is definitely not a negligible figure, and it goes to show that this was not a marginal phenomenon and that the Vikings were able to understand the place-names they encountered. 
therefore the role of analogy in place-name formation should not be underestimated either. It is very likely that English speakers gave to their outlying settlements names in porp (Cameron 1996: 80), and the place-name evidence also seems to support this assumption. There are altogether 198 instances of placenames in porp which have a personal name specific, 51 of these $(25.75 \%)$ have an English personal name and $130(65.65 \%)$ have a Scandinavian personal name as their first element. In contrast, out of 362 settlement names in $b y$, 291 $(80.38 \%)$ have Scandinavian personal name specifics and only $34(9.39 \%)$ have English personal name specifics, and there are only 37 (10.23\%) appellatival place-names in this group. There are also a great number of names which are new formations and are first attested after the conclusion of the Domesday survey, sometime as late as the $13^{\text {th }}$ century, by which time direct contact with the Scandinavians had long ceased to exist. Furthermore, Scandinavian personal names were not exclusively borne by people of Scandinavian descent, but they were on many occasions adopted by the English, as Norman personal names were also adopted after the Norman Conquest. Therefore, either group of speakers could have engaged in the creation of those settlement names which contain personal names of Scandinavian origin.

Place-name formation cannot be considered a random, haphazard phenomenon, because all proper nouns ultimately originate as semantically transparent, meaningful lexical items, adequately descriptive of whatever they denote, therefore the same phonological, morphological, and word formational rules and constraints apply to them as apply to the whole of the language and to the formation of other word classes (cf. Gammeltoft 2007: 481). These originally transparent names are then very often obscured and rendered opaque by folk etymology and/or the regular, historical changes that take place in the language $^{9}$. The wide variety of issues related to the semantics of place-names and proper nouns cannot be tackled in this paper, however the following relevant point shall be made. The common nouns that make up those place-names which are not derived from personal names can gradually lose their appellative meaning in the given place-name and begin to refer to only one unique entity, i.e. the locality, a process which Blanár (2009: 89) termed 'onymisation'. However, it cannot be determined at exactly which point during its development the appellatival origin of a place-name or a personal name becomes obscured. Furthermore, this process does not mean that all names from the moment they are created are by definition always completely devoid of any meaning and their sole

9 The example of the development of the name York is a well-known and frequently cited one, and it provides quite a good glimpse into the various processes that affect toponyms and the ways in which various layers of settlers and inhabitants treat the place-names they encounter (for an in-depth analysis see Fellows-Jensen 1987). 
purpose is to function as mere labels used for the identification of localities. Names do carry meaning during the phase when they are still transparent and analysable. Onymisation should not be a bar for the appropriation and adaptation of foreign settlement names either, because the etymological background and, more importantly, being able to attribute lexical meanings to semantically opaque place-names are irrelevant factors for speakers (cf. Dalberg 2008 [1977]: 52). Similarly, being familiar with the etymological background of any word that is not a name is also irrelevant for the average language user. Folk etymology and its two components of a reanalysis and analogy are especially salient factors in making sense of the obscured toponyms. Names (and to some extent common nouns and other 'non-proper' types of words) do not have to be transparent and readily analysable, because if speakers cannot make sense of certain names (or nouns, etc.) they are very likely to resort to the practice of folk etymology, which helps them connect the unanalyzable item with a familiar, analysable one which often results in an erroneous interpretation, one that is perceived to make sense or at least enables the speakers to attribute a meaning to it. The occurrence of place-names in everyday speech is likely to be quite infrequent but nevertheless they do not enjoy any special position, treatment or attention in the average speaker's language use. Lastly, place-names and personal names are usually very strongly tied to personal and group identities; therefore attributing certain perceived qualities to them is quite a commonly employed practice.

A usual distinction or differentiation is made between the lexicon and the onomasticon which is justifiable if the questions at hand are looked at from a theoretical perspective but it is, I maintain, rather unnecessary from a practical point of view. It is not always and not entirely correct to assume that common nouns fulfil the role of categorization and establishing group membership, while proper nouns, or names, fulfil the role of identification and singling out and labelling individual entities, places or persons. The generic elements of placenames are always appellatives and their purpose is to classify, doing so by categorizing the locality in question as an outlying farmstead, a secondary settlement or a village, just to name the most frequently occurring ones. Affixes build words, generics build toponyms. Basically, appellatival toponyms are rightheaded endocentric compounds, which get their main category (i.e. the aforementioned farmstead, etc.) from the lexical meaning of the generic. On the formal level compound place-names consisting of a specific and a generic develop and behave in much the same way as non-transparent compounds $\mathrm{do}^{10}$. The

10 In this case the term non-transparent does not refer exclusively to exocentric compounds, which are by nature non-transparent, but rather to a specific kind of compounds, sometimes labeled darkened compounds, ones which were originally made up of two (or more) free 
main argument here, then, is that a strict, binary differentiation of the lexicon and the onomasticon is unpractical, because names originate in the lexicon and elements of the onomasticon can also be used in a lexical function. In summary the following four major types of Norse-related place-name formation can be distinguished:

(i) pure Scandinavian formations

(ii) personal name hybrids ${ }^{11}$ (Grimston-hybrids)

(iii) appellative hybrids (Carlton-hybrids)

(iv) Scandinavianized place-names

For the purpose of this paper, Scandinavianized place-names, chiefly those created through the substitution of cognates, and appellative hybrids are of highest importance, because they can be better indicators of code mixing than personal name hybrids, given that personal names would rarely be Scandinavianized or Anglicized in these circumstances.

\subsection{Language and strata}

The type of the contact of English with Scandinavian and the influence of the latter on the former was intimate, pervasive, and most probably dominantly superstratal with adstrate-like characteristics. Naturally the extent and intensity of the English-Scandinavian contact situation varied from region to region as well as across time and we cannot speak of a distinct, solid wave of influence which uniformly affected the English language ${ }^{12}$, yet the overall superstratal influence is clearly indicated by the fact that the trigger for the emergence of the contact situation was the conquest by the Vikings and the language of the victo-

morphemes and during the historical development of the given language they became one single unit, no longer analyzable into separate words, for instance ModE lord $<$ OE hlaford $<$ hlafweard 'guardian of the bread'.

11 Owing to the fact that category names such as Grimston-hybrid, 'Grímr's village' (FellowsJensen 1972: 128, Ekwall 1980: 206, Mills 1998: 157) and Carlton-hybrid, 'village of the freemen or peasants' (Fellows-Jensen 1978: 183, Ekwall 1980: 87-88, Mills 1998: 71) entail a sense of exclusivity in favor of a Scandinavian + English order and origin of elements, I propose the use of a more neutral and broader personal name hybrids and appellative hybrids, respectively, which can also include an English + Scandinavian order and origin.

12 In this situation, one also has to bear in mind that neither the Old Norse nor the Old English language constituted a standardized, uniform entity, as there existed regional variation and dialectal differences in both cases. Furthermore, the Scandinavian loanwords found in Modern English are the ones which have survived the Norman French invasion and its massive linguistic impact and also passed standardization after becoming part of the standard variety, largely based on the West Saxon dialect and Southern English. 
rious group is typically a superstrate language (Thomason \& Kaufman 1991: 116, Hickey 2010: 7, Vennemann 2011: 218). Furthermore, this effect is also observable in the breadth and variety of Scandinavian loanwords that have entered the English language, which on occasion replaced native English terms, in other instances introduced new words to fill lexical gaps, and in some cases led to the emergence of etymological doublets. This rather vast number of borrowed lexical items, as demonstrated by Moskowich (2012: 110-122), belong to quite a wide variety of semantic fields, therefore they are not exclusively or dominantly found in the rather broad and elusive category of "everyday life", as it is very often posited. Vennemann (2011: 242) and Lutz (2013: 567) also raise awareness about the issue that many of the Scandinavian loans in the field of law and administration were superseded by words borrowed from French following the Norman Conquest, which obscured the evidence of the Norse domination over the political system (at least in the Danelaw), thus one could be led to erroneously believe that the language of the Scandinavians did not exert such a significant superstratal effect.

Evidence for the most likely, partially adstrate-like nature of the AngloScandinavian contact situation could be found if one subscribes to the scenario of a secondary, peasant migration, which followed the campaigns and conquests of the micel here. It could be postulated that the massive settlement of free peasants brought about a state of affairs in which neither the speakers of English, nor those of Old Norse were in a subordinate or superordinate position. In the Danelaw area the Danish law prevailed, yet there were no clearly observed boundaries of identity, ethnicity, and nationality between the English and the Danes (Hadley 2002: 52). Further pieces of evidence can be provided by the sheer number of Norse-related place-names (be they purely Scandinavian, Scandinavianized, or English-Scandinavian mixed ones), which would hint at a larger-scale settlement and population mixing, disregarding whether or not this was the result of internal colonization, as discussed above. This situation is in stark contrast with the one that was the result of the Norman Conquest, which meant a complete replacement of the Anglo-Saxon ruling class with an aristocracy of Norman French origin, and in this case Norman French, the language of the invaders was clearly and purely superstratal.

Concerning linguistic interference, Thomason \& Kaufman (1991: 35) point out that the main determinant of the outcome of language contact is the speakers' sociolinguistic history and not the structure of their language. Linguistic and structural constraints all fail in favour of social and cultural factors conditioning the outcome of language contact. They argue that the social factors determine the direction of the interference, i.e., which language borrows and which supplies the forms borrowed, also the extent of the interference, i.e., which layers are affected and how deeply, and finally what kind of features are 
transferred between the languages. The explanation may seem banal, but language change, and contact induced language change, as Thomason (2000) rightly observes, is largely unpredictable.

\section{Borrowing, code-switching, and place-names}

For the purposes of this paper, a broad definition of code-switching (and codemixing) is adopted, namely that code-switching is "the use of more than one language during a single communicative event" (Muysken 2011: 301-302), while code-mixing is "the alternation of two invariant systems in a single discourse" (Muysken 2000: 123). In the analyses of code-switching this communicative event is usually taken to be an utterance, yet in our case it is the production of a compound word, which is then used as a place-name. Also, for the purposes of this paper, no sharp distinction is to be made between codeswitching and code-mixing, the two terms are used interchangeably and taken to refer to essentially the same phenomenon ${ }^{13}$. The practices of code-switching and code-mixing are closely related to bilingualism, and engaging in them requires a degree of bilingual competence. Attempts made at defining grammatical constraints and rules of code-switching, code-mixing, and contact induced language change are ultimately unsuccessful at providing universal rules to which all instances of CS can and will conform (cf. Gardner-Chloros \& Edwards 2004). The linguistic behaviour and code choice of the speaker greatly depends on pragmatic factors (such as power distance, perceived prestige of the affected languages, familiarity of the interlocutors, context in which the exchange takes place, etc.) and therefore it is difficult to lay down general rules. Instead of attempting to establish binary rules, it is perhaps more advisable to observe and examine frequencies with which given types of switching are likely to occur in given types of communicative settings.

If speakers engage in a process of code-switching or code-mixing, then they possess a degree of linguistic competence in both of the languages they mix ${ }^{14}$, and in case the two languages involved are genetically related to each other, then essentially the speakers perform an act of cognate substitution. The message and the communicative content that the speaker intends to convey this way

13 As can be seen from the definition, and as Appel \& Muysken (2005 [1987]: 118) also observe "it is not always easy to distinguish between the different types [of switching and] sociological studies of code-switching tend to generalize across the [...] kinds of switches". It should be mentioned, however, that code-mixing is typically used when referring to intrasentential switching, but such a distinction is not of crucial importance here because this paper deals with switching within lexical items.

14 In the case of the Anglo-Scandinavian contact situation this competence was likely achieved through mutual intelligibility. 
is exactly the same as it would be if it was conveyed in only one of the languages and the only aspect that is different is the surface form ${ }^{15}$.

In their seminal work, Thomason \& Kaufman provide their definition of borrowing, namely that it is "the incorporation of foreign features into a group's native language [while] the native language is maintained, but is changed by the addition of the incorporated features" (1991:37), while earlier Haugen (1950: 212) defined the phenomenon as "the attempted reproduction in one language of patterns previously found in another". It is rather difficult to find the demarcation line between borrowing and diachronic code-switching, and as the previously cited definitions show, the key emphasis is on the concepts of incorporation and reproduction. Code-switching also makes extensive use of these processes. Mixed language utterances and foreign lexical items show the incorporation of elements of one language in the structure of another, which are very often transformed both phonologically, so as to be more congruent with the phonological system of the recipient language, and morphologically through the addition of inflectional and other bound morphemes, thereby they are reproduced utilizing the phonological and morphological inventory of the language into which the foreign elements are inserted. Furthermore, a key distinguishing feature between code-switching and borrowing seems to be the frequency of occurrence, namely that those foreign elements which occur with a higher frequency in a given language are more likely to be borrowed words than the result of code-switching. Another way of distinguishing between the two phenomena is the use of foreign elements by monolingual speakers, which would mean that the lexical items in question are borrowings. Unfortunately we have no information about or evidence of this concerning the OE-ON contact situation.

Following Muysken's (2000) three-way classification and typology of intrasentential code-mixing, whereby he establishes the categories of insertion, alternation and congruent lexicalization, it can be argued that the situation presented here is in fact a manifestation of congruent lexicalization, which is not of an intrasentential nature, but word internal or intralexemic instead (cf. Muysken 2000: 137). Insertion refers to the type of code-mixing whereby a constituent is embedded in the structure of another language, alternation means that the involved languages remain separated, i.e., elements of the languages alternate with each other, and congruent lexicalization occurs when two languages share the basic structure, into which elements from either language can be inserted (Muysken 2000: 127). This type of CM happens when closely related and highly similar languages of roughly equal prestige are affected and there is no overt

15 Code choice can also be the manifestation of one's conscious and deliberate expression of identity and can naturally bring about pragmatic issues, the discussion of which lies outside the scope of the present paper. 
language separation in terms of prestige (Lipski 2009: 2-3). This was very much the configuration in the case of the contact between English and Norse, when the two languages were very much similar ${ }^{16}$, with a degree of mutual intelligibility, and as discussed before were in a partially adstratal relationship. After the data has been surveyed, it will be demonstrated in Section 5 that the situation at hand indeed conforms to the category of congruent lexicalization.

\section{The material}

The place-name data for the analysis was chiefly drawn from the place-name dictionaries of Ekwall (1980) and Mills (1998, 2011), with additional data of Scandinavianized forms, lost villages, deserted and depopulated settlements being drawn from Fellows-Jensen's three major regional studies of Scandinavian settlement names in Yorkshire (1972), the East Midlands (1978), and the North West (1985). Altogether 1,915 relevant place-names have been collected, of which a special corpus has been compiled for the purposes of the present study. The origins of the place-name elements were determined on the basis the primary data sources (Fellows-Jensen 1972, 1978, 1985, Mills 1998) and Ekwall's (1980) dictionary as well as Reaney's (1987) reference work.

\section{Results and discussion}

From the survey and analysis of the collected place-name data it has emerged that Scandinavian specifics combined with Scandinavian generics is the most frequently occurring type both in the category of settlement names with personal name specifics (51\%), and non-personal name (or appellatival) specifics (49\%). Table 1 summarizes the distribution of place-names with personal name specifics $(\mathrm{N}=1056)$, and the distribution of place-names with non-personal name specifics $(\mathrm{N}=859)$.

16 There were, however key phonological differences which are reflected in some of the Scandinavianized forms, such as the substitution of [sk] for [S] as in Fiskerton ('fisherman's village' containing OE fiscere 'fisherman' with [sk]), or [k] for [t $\left.\int\right]$ as in Digby $(<\mathrm{ON} *$ diki-by' 'village at the ditch' with $[\mathrm{k}]$ ), to name two of the most frequently occurring ones, among others. Due to the lack of space here, for a detailed, comprehensive treatment of phonological differences see Townend (2002: 31-41, 61-63). 
Table 1. Distribution of place-names with personal and non-personal name specifics

\begin{tabular}{|c|c|c|c|c|c|c|c|}
\hline \multicolumn{4}{|c|}{ Personal names $(\mathrm{N}=1056)$} & \multicolumn{4}{|c|}{ Appellative names $(\mathrm{N}=859)$} \\
\hline specific & generic & count & per cent & specific & generic & count & per cent \\
\hline Norse & Norse & 547 & $51.80 \%$ & Norse & Norse & 419 & $48.78 \%$ \\
\hline Norse & English & 214 & $20.27 \%$ & English & Norse & 152 & $17.69 \%$ \\
\hline English & Norse & 100 & $47 \%$ & Norse & English & 126 & $14.67 \%$ \\
\hline $\mathrm{E} / \mathrm{N}^{17}$ & English & 53 & $5.02 \%$ & Scandina & jianized & 100 & $11.64 \%$ \\
\hline $\mathrm{E} / \mathrm{N}$ & Nors & 41 & $3.88 \%$ & $\mathrm{E} / \mathrm{N}$ & Norse & 43 & $5.01 \%$ \\
\hline Celtic & Nor & 35 & $3.31 \%$ & $\mathrm{E} / \mathrm{N}$ & Englisl & 9 & $1.05 \%$ \\
\hline Scandina & nized $^{18}$ & 24 & $2.27 \%$ & English & $\mathrm{E} / \mathrm{N}$ & 5 & $0.58 \%$ \\
\hline Germanic $^{19}$ & Norse & 19 & $1.80 \%$ & Norse & $\mathrm{E} / \mathrm{N}$ & 5 & $0.58 \%$ \\
\hline French & Norse & 10 & $0.95 \%$ & & & & \\
\hline English & $\mathrm{E} / \mathrm{N}$ & 8 & $0.76 \%$ & & & & \\
\hline Norse & $\mathrm{E} / \mathrm{N}$ & 5 & $0.47 \%$ & & & & \\
\hline
\end{tabular}

The data in table 1 shows the unassailable dominance of purely Scandinavian formations, which, as discussed in the previous sections, hints at rather extensive settlement. It can also be seen that appellatival names contain a significantly higher proportion of Scandinavianized items, which seems to be in accordance with the presupposition formulated in Section 2.1., namely that personal names are less likely to undergo Scandinavianization or Anglicization.

Table 2 shows the distribution of the first fifteen most frequently occurring tokens of Old Norse $(\mathrm{N}=1,199)$ and Old English $(\mathrm{N}=413)$ generics.

17 Either Old English or Old Norse: dubious cases in which the origin of the first element cannot be determined with certainty on the basis of the attested forms; for instance, Autby (attested forms in the Domesday Book include Aluuoldebi, Alwoldebi, and Alduluebi), a depopulated settlement which contains either the OE personal name Elfweald or the (rare) ON personal name Alfvaldr (Fellows-Jensen 1978: 34), or the appellatival Bowthorpe (attested Domesday Book forms include Bergestorp and Buretorp), a lost settlement which contains either OE beorg or ON berg 'hill' (Fellows-Jensen 1978: 104).

18 Scandinavianized names are defined as toponyms containing an English specific and an English generic, the first element of which has undergone phoneme substitution in order to accommodate the English name to the Scandinavian phonological system, for instance, the previously mentioned Fiskerton and Digby.

19 In this case Germanic refers to continental Germanic names. 
Table 2. Distribution of Old Norse and Old English generics

\begin{tabular}{|c|c|c|c|c|c|c|c|}
\hline \multicolumn{4}{|c|}{ Old Norse $(\mathrm{N}=1199)$} & \multicolumn{4}{|c|}{ Old English $(N=413)$} \\
\hline generic & meaning 20 & count & per cent & generic & meaning & count & per cent \\
\hline$b y^{\prime}$ & village & 585 & $48.79 \%$ & $t \bar{u} n$ & village & 229 & $55.45 \%$ \\
\hline porp & $\begin{array}{l}\text { secondary } \\
\text { settlement }\end{array}$ & 273 & $22.77 \%$ & burh & $\begin{array}{l}\text { dwelling } \\
\text { place }\end{array}$ & 27 & $6.54 \%$ \\
\hline holmr & $\begin{array}{l}\text { water- } \\
\text { meadow }\end{array}$ & 43 & $3.59 \%$ & $w \bar{l} c$ & farm & 18 & $4.36 \%$ \\
\hline dalr & valley & 42 & $3.50 \%$ & lèah & clearing & 17 & $4.12 \%$ \\
\hline pveit & clearing & 38 & $3.17 \%$ & ford & ford & 14 & $3.39 \%$ \\
\hline toft & curtilage & 30 & $2.50 \%$ & wella & well & 12 & $2.91 \%$ \\
\hline lundr & grove & 26 & $2.17 \%$ & $\cot$ & cottage & 12 & $2.91 \%$ \\
\hline haugr & hill & 23 & $1.92 \%$ & halh & $\begin{array}{l}\text { nook of } \\
\text { land }\end{array}$ & 11 & $2.66 \%$ \\
\hline bekkr & beck & 20 & $1.67 \%$ & denu & valley & 9 & $2.18 \%$ \\
\hline skáli & hut & 17 & $1.42 \%$ & hām & homestead & 8 & $1.94 \%$ \\
\hline vað & ford & 16 & $1.33 \%$ & byrig & town & 8 & $1.94 \%$ \\
\hline$v i ð r$ & wood & 14 & $1.17 \%$ & croft & enclosure & 7 & $1.69 \%$ \\
\hline berg & hill & 12 & $1.00 \%$ & $\bar{e} g$ & island & 7 & $1.69 \%$ \\
\hline kjarr & marsh & 10 & $0.83 \%$ & brycg & bridge & 7 & $1.69 \%$ \\
\hline skógr & wood & 10 & $0.83 \%$ & hēafod & headland & 6 & $1.45 \%$ \\
\hline
\end{tabular}

In the cases of Anglo-Scandinavian hybrid place-names it cannot be established with certainty which language functions as the receiving language, i.e., the one which broadly speaking supplies the overall structure, and which functions as the language whose forms are inserted into the structure. It is similarly difficult, or even impossible, to declare in certain hybrid names whether they are the result of cognate substitution or they were formed by an "Anglo-Scandinavian" population (Fellows-Jensen 1978: 205). This is in accordance with the characteristics of congruent lexicalization, namely that it "often involves bidirectional code-mixing [emphasis original] since there is no matrix language" (Muysken 2000: 132). It can be seen from the data that there are 126 appellatival hybrids (14.67\% of all such formations) which have an $\mathrm{ON}+\mathrm{OE}$ order and origin of elements, while $152(17.69 \%)$ appellatival hybrids follow the opposite order. This means that the number of $\mathrm{ON}+\mathrm{OE}$ and $\mathrm{OE}+\mathrm{ON}$ hybrids are roughly the same, so there is indeed no dominant matrix language. The shared linguistic structure and the other similarities existing between the languages facilitate

20 Meanings of Old Norse and Old English generics given here are based on Fellows-Jensen (1972, 1978, 1985), Ekwall (1980), and Mills (1998). 
congruent lexicalization and bring about bidirectional mixing. Many of the Scandinavian and Scandinavianized place-names are first attested only from 1086, in the records of the Domesday Book, therefore there is no reliable data available about the date when these place-names could have been first used, and there is no evidence of whether they were transformed from English names or were new coinages. It is very likely, however, that hybrid names are later formations than purely Scandinavian ones, which were created after the initial phase of settlement, whereas hybrid ones came about in a period when population mixing, socio-political adjustment and assimilation was taking place (cf. Fellows-Jensen 1995: 58).

It can also be argued that the creation of hybrid names and names containing cognate substitution both resulted in the production of mixed names, which are made up of elements from two different languages, and could therefore constitute instances of code-mixing. This situation, however, cannot be classified as codeswitching or borrowing with certainty. Borrowed elements can either fill lexical or semantic gaps, oust native terms or, in some cases, lead to the continued use of native items but with a restricted or modified meaning or as part of a different stylistic register, rather than be used in such a fashion that allows their coexistence alongside native terms without semantic change or stylistic modification occurring in either of the affected words. In our case, quite a vast array of different appellatival specifics are used, most of them rather infrequently, and - due to the fact that none of these elements displaced any of the English ones -the situation at hand is more likely to be classified as code-mixing than borrowing.

Gammeltoft (2007: 481) argues that

\begin{abstract}
"[w] $[\mathrm{wen}$ a place-name or a place-name element has been borrowed from one language to another; it becomes part of the borrowing language's onomasticon. From then on it may be used to coin new names in that language. Thus, when a placename appears to be a hybrid of elements from two languages, it is in reality not. It is a monolingual coinage utilising a borrowed place-name or a borrowed placename element."
\end{abstract}

This explanation of "pseudo-hybrid" formation through borrowing can definitely be true for hybrid names in $b \dot{y}$, porp, and tūn, all of which have a very high frequency of occurrence, making borrowing a likely explanation. However, it seems rather unfeasible that such a huge number of diverse elements, both specifics and generics, all capable of describing minute distinctions in meaning, were borrowed into either Old English or Old Norse to create monolingual hybrids, while maintaining their subtle distinctions of meaning. It seems much more likely that these formations are indeed true hybrid ones.

Old English and Old Norse generics, on the other hand, show less overlap than the specifics, which could have led to the borrowing of the frequently oc- 
curring elements for which no native English term was available, e.g., toft 'homestead, curtilage', holmr 'water meadow', pveit 'clearing'. It should also be emphasized that borrowing is not something that happens abruptly and instantaneously, but it is the terminal point of a gradual process, which can, and quite probably does, include code-switching and/or code-mixing, and which is rather closely related to frequency of use, because if a foreign element is used infrequently in a given language then it is much more likely to be an isolated case of code-switching.

It can be seen from the data above, that habitative generics, and thus habitative names, seem to be dominant both in the case of Norse and English. The Norse material shows a similar, long-tailed distribution of frequencies as does the group of English generics, and, more importantly, it shows a great variety of different elements. This means that settlement names created using these items cannot reflect the use of a few, fossilized generics, but rather reflect that they were created utilizing a wide repertoire of productive and actively used elements capable of capturing minute differences in meaning.

Concerning the data, it is revealed by the analysis that 20 different generics occur in the group of English $+\operatorname{Norse}(\mathrm{OE}+\mathrm{ON})$ appellative hybrids and 37 different generics are to be found in the Norse + English $(\mathrm{ON}+\mathrm{OE})$ group of settlement names. The type-token ratio of generics in the case of EnglishScandinavian hybrids is 0.131 with 20 generic types and in the group of Scandinavian-English hybrids the ratio is 0.293 with 37 generic types. Due to the higher degree of heterogeneity in $\mathrm{ON}+\mathrm{OE}$ toponyms it can be assumed that those names were created by a Scandinavian population either through cognate substitution or as new formations through using English generics. In the first group by (55 occurrences out of 152, 36.18\%) and borp (28 instances, or $18.42 \%$ ) are by far the most frequently occurring elements, followed by $b e k k r$ (8 instances, or $5.26 \%$ ), while in the other group tün has the highest frequency (40 out of 126, 31.74\%), followed by leah (5 instances, or 3.96\%) and ford (5 occurrences, or $3.96 \%$ ). There is an observable difference between these two types, which is most clearly reflected by the fact that the top two generics in the $\mathrm{OE}+\mathrm{ON}$ group account for more than half $(54.6 \%)$ of all the token occurrences, while in the $\mathrm{ON}+\mathrm{OE}$ group there is only one element, which has an outstanding frequency, and the other ones show more sporadic distribution.

This means that it is unlikely that such a great array of different English generics were borrowed by the Scandinavians, and vice versa. It is possible that $b y$ and porp were accepted into English where they were used productively, as discussed before, and that OE tün made its way into Scandinavian, where it became productive. It is also likely that English appellatival names in $b y$ and porpare young formations, as well as Scandinavian appellative names in tün, given that tün was a very productive English generic (Ekwall 1980: xiv-xv), 
and by and porp were highly productive Scandinavian ones. It should also be mentioned that while ON porp had its cognate in Old English as prop, its incidence is far lower than its Scandinavian counterpart, and occurs very infrequently in purely English, non-hybrid settlement names outside the Danelaw

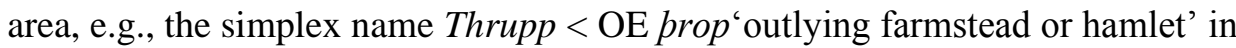
Gloucestershire, so much so that Mills (2011) cites only a handful of examples for its occurrence, most of which come from regions that were subject to Scandinavian influence, such as Throphill (Northumbria, first attested in 1166 as Trophill) 'hamlet hill', from OE prop 'outlying farmstead, hamlet' and OE hyll 'hill', in which case the element is used in the function of the specific (Mills 2011: 428), and Abthorpe (Northamptonshire, first attested in 1190 as Abetrop), 'outlying farmstead or hamlet of a man called $A b b a$ ', from an OE personal name and either the OE generic prop or the ON genericporp (Mills 2011: 3). Furthermore, OE tūn also had its cognate in Old Norse as tún, but as FellowsJensen (1978: 175-176) has demonstrated, its occurrence in Denmark is very infrequent and the element was quite probably unproductive at the time of the Viking conquest of England, therefore it is unlikely that this element was either transplanted by the Viking settlers to England or that it played a significant role, or any role at all, in the facilitation of the emergence of Scandinavian-English hybrid place-names in -tūn in England ${ }^{21}$.

The English-Scandinavian hybrid names treated in this paper could be analogical formations based on existing $\mathrm{ON}+\mathrm{ON}$ and $\mathrm{OE}+\mathrm{OE}$ names, or they could have been created through the active and productive use of the generics. In both groups a rather heterogeneous selection of specifics can be found, with a predominance of adjectives and nouns denoting humans. The code-mixing found in those hybrid settlement names which contain a Scandinavian specific and an English generic likely arose in the process of the Norse population's assimilation and shift to English, and was probably necessitated by the situation itself. The emergence of most of the mixed place-names discussed above cannot be satisfactorily explained as borrowings, on the grounds of having two Norse generics and one English generic with an outstandingly high frequency of occurrence and 18 and 36 more types of generics from Old Norse and Old English, respectively, with significantly lower frequencies. Nor can they be explained in a satisfactory way as being young mixed formations, due to the gap-

21 However, as Fellows-Jensen (1978) also notes, this generic occurred rather frequently in Norway, Iceland, and central Sweden but with a different meaning and borne by different types of settlements than in England or Denmark. Since the vast majority of Scandinavian settlers in England, especially in Yorkshire and the East Midlands, came from Denmark, the strongest piece of evidence against the conflation of OE tün and ON tún seems to be the fact that the latter had already obsolesced by the time the Danes came into any sort of contact with the English. 
ing holes in textual evidence regarding settlement names antedating both the Viking and the Norman French invasions, therefore it is proposed that the hybrid names can be labelled instances of intralexemic (or word-internal) cognate substitution ("non-constituent mixing", cf. Muysken 2000: 129, 137), which might form a broader subtype of historical code-mixing, more specifically of congruent lexicalization. In this case, there is a mixed compound word, which is a complex lexeme, the overall structure of which is shared by both languages, because Old English and Old Norse shared their place-name formational practices, which meant a specific + generic order of elements and the use of the dative plural and genitive cases. For word-internal cognate substitution, a preexisting form is required, which in our case is supplied by English, into which forms from a closely related cognate language can be inserted thereby creating cognate substitution and a mixed-language lexical item.

\section{Conclusions}

In this paper it was presented and argued that those hybrid appellatival placename formations which emerged as a result of the English-Scandinavian language contact situation can be classified as instances of the word internal (or intralexemic) code-mixing of the congruent lexicalization type, and in the cases of Scandinavianized names as instances of intralexemic cognate substitution. This paper did not intend to go anywhere beyond the realm of language, therefore it did not aim to make any claims or draw any conclusions regarding the distribution of Scandinavian settlement based on the place-names alone, which, as the author is convinced, cannot be viewed as the sole indicator of such distribution.

\section{REFERENCES}

Appel, René \& Pieter Muysken. 2005 (1987). Language contact and bilingualism (Amsterdam Academic Archive). Amsterdam: Amsterdam University Press.

Bullock, Barbara E.\&Almeida J.Toribio. 2009. Themes in the study of code-switching. In Barbara E. Bullock \&Almeida J. Toribio (eds.), The Cambridge handbook of linguistic codeswitching (Cambridge Handbooks in Linguistics), 1-18. Cambridge: Cambridge University Press. doi: 10.1017/CBO9780511576331.002

Blanár, Vincent. 2009. Proper names in the light of theoretical onomastics. Namenkundliche Informationen 95/96. 89-157.

Cameron, Kenneth. 1996. English place-names (new edn.). London: Batsford.

Dalberg, Vibeke. 2008 [1977]. The psychology of place-name changes. In Gillian FellowsJensen, Peder Gammeltoft, Bent Jørgensen \& Berit Sandnes (eds.), Name and place: Ten essays on the dynamics of place-names (Navnestudier 40), 51-60. Copenhagen: University of Copenhagen. 
Ekwall, Eilert. 1980. The concise Oxford dictionary of English place-names (4th edn.). Oxford: Clarendon Press.

Fellows-Jensen, Gillian. 1968. Scandinavian personal names in Lincolnshire and Yorkshire (Navnestudier 7). Copenhagen: Akademisk Forlag.

Fellows-Jensen, Gillian. 1972. Scandinavian settlement names in Yorkshire (Navnestudier 11). Copenhagen: Akademisk Forlag.

Fellows-Jensen, Gillian. 1978. Scandinavian settlement names in the East Midlands (Navnestudier 16). Copenhagen: Akademisk Forlag.

Fellows-Jensen, Gillian. 1985. Scandinavian settlement names in the North West (Navnestudier 25). Copenhagen: C. A. Reitzels Forlag.

Fellows-Jensen, Gillian. 1987. York. Leeds Studies in English 18. 141-155.

Fellows-Jensen, Gillian. 1995. The light thrown by the early place-names of Southern Scandinavia and England on population movement in the Migration Period. In Edith Marold \& Christiane Zimmermann (eds.), Nordwestgermanisch (Ergänzungsbände zum Reallexikon der germanischen Altertumskunde 13), 57-77. Berlin: de Gruyter.

Gammeltoft, Peder. 2007. "Scandinavian naming-system in the Hebrides: A way of understanding how the Scandinavians were in contact with Gaels and Picts? In Beverley B. Smith, Simon Taylor \& Gareth Williams (eds.), West over sea: Studies in Scandinavian sea-borne expansion and settlement before 1300 (Northern World 31), 479-495. Leiden: Brill.

Gardner-Chloros, Penelope \& Malcolm Edwards. 2004. Assumptions behind grammatical approaches to code-switching: When the blueprint is a red herring. Transactions of the Philological Society 102(1): 103-129. doi: j.0079-1636.2004.00131.x

Hadley, Dawn M. 2000. The northern Danelaw: Its social structure c.800-1100 (Studies in the early history of Britain). London: Leicester University Press.

Hadley, Dawn M. 2002. Viking and native: Re-thinking identity in the Danelaw. Early Medieval Europe 11(1). 45-70. doi: 10.1111/1468-0254.00100

Haugen, Einar. 1950. The analysis of linguistic borrowing. Language 26(2): 210-231. doi: $10.2307 / 410058$

Hickey, Raymond. 2010. Language contact: Reconsideration and reassessment. In Raymond Hickey (ed.), The handbook of language contact (Blackwell Handbooks in Linguistics), 1-29. Chichester: Wiley-Blackwell. doi: 10.1002/9781444318159.ch

Janzén, Assar. 1972. The Viking colonization of England in the light of place-names. Names 20(1): $1-25$.

Lipski, John M. 2009. "Fluent dysfluency" as congruent lexicalization: A special case of radical codemixing. Journal of Language Contact 2(2): 1-39. doi: 10.1163/000000009792497742

Loyn, Henry. 1994. The Vikings in Britain (rev. edn.) (Historical Association Studies). Oxford: Blackwell Publishers.

Lutz, Angelika. 2013. Language contact and prestige. Anglia 131(4): 94-122. doi: 10.1515/anglia-2013-0065

Mills, Anthony D. 1998. A dictionary of English place-names (new edn.). Oxford: Oxford University Press.

Mills, Anthony D. 2011. A dictionary of British place-names (rev. edn.). Oxford: Oxford University Press.

Moskowich, Isabel. 2012. Language contact and vocabulary enrichment: Scandinavian elements in Middle English (Studies in English Medieval Language and Literature 34). Frankfurt am Main: Lang. 
Muysken, Pieter. 2000. Bilingual speech: A typology of code-mixing. Cambridge: Cambridge University Press.

Muysken, Pieter. 2011. Code-switching. In Rajend Mesthrie (ed.), The Cambridge handbook of sociolinguistics, 301-314. Cambridge: Cambridge University Press.

Reaney, Percy H. 1987. The origin of English place-names (9th impr.). London: Routledge and Kegan Paul.

Sawyer, Peter H. 1962. The age of the Vikings. London: Arnold.

Schendl, Herbert \& Laura Wright. 2011. Code-switching in early English: Historical background and methodological and theoretical issues. In Herbert Schendl \& Laura Wright (eds.), Code-switching in early English (Topics in English Linguistics 76), 15-46. Amsterdam: Mouton de Gruyter. doi: 10.1515/9783110253368.15

SPNLY = Fellows-Jensen, Gillian (1968).

SSNEM = Fellows-Jensen, Gillian (1978).

SSNNW = Fellows-Jensen, Gillian (1985)

SSNY = Fellows-Jensen, Gillian (1972).

Thomason, Sarah G. \& Terence Kaufman. 1991. Language contact, creolization and genetic linguistics. Berkeley: University of California Press.

Thomason, Sarah G. 2000. On the unpredictability of contact effects. Estudios de Sociolingüística 1(1): 173-182. doi: 10.1558/sols.v1i1.173

Townend, Matthew. 2002. Language and history in Viking Age England: Linguistic relations between speakers of Old Norse and Old English (Studies in the Early Middle Ages 6). Turnhout: Brepols.

Vennemann, Theo. 2011. English as a contact language: Typology and comparison. Anglia 129(3/4): 217-257. doi: 10.1515/angl.2011.084 